\title{
Water Quality Remediation Using Geotextile in Fish Hatchery Systems
}

\section{Abentin Estim* and Saleem Mustafa}

Borneo Marine Research Institute, Universiti Malaysia Sabah, Malaysia

\begin{abstract}
This study was designed to use Aquamat ${ }^{\mathrm{TM}}$ in the daily exchange and flow-through culture systems of fish hatchery for improving the quality of seawater. Aquamat ${ }^{\mathrm{TM}}$ is a commercial innovative product fabricated from highly specialized synthetic polymers that forms a three dimensional structure. Results showed that the Aquamat ${ }^{\mathrm{TM}}$ reduced ammonia (NH3-N), total suspended solids (TSS) and dissolved oxygen (DO) concentrations in the daily exchange system but not in the flow-through system. Average values of $\mathrm{NH}_{3}-\mathrm{N}(\mathrm{F}=0.028 ; \mathrm{t}=-2.006 ; \mathrm{P}=0.047)$, TSS $(F=4.550 ; t=-2.787 ; P=0.006)$ and $D O(F=25.085 ; t=-2.833 ; P=0.005)$ concentrations were significantly lower in the culture tank with Aquamat ${ }^{\mathrm{TM}}$ than the culture tank without Aquamat ${ }^{\mathrm{TM}}$. Fish biomass gain was significantly higher $(F=2.177 ; t=-4.296 ; P=0.001)$ in the culture tanks of with Aquamat ${ }^{T M}$ than without Aquamat ${ }^{\mathrm{TM}}$. The bacterial density was significantly higher $(\mathrm{F}=11.437 ; \mathrm{df}=2 ; \mathrm{P}=0.000)$ on the surface of Aquamat ${ }^{\mathrm{TM}}$ than in the seawater of culture tanks with and without Aquamat ${ }^{\mathrm{TM}}$. This study suggests that the Aquamat ${ }^{\mathrm{TM}}$ provides surface area for fish to hide from cannibalism activity, thereby reducing mortality. It was also found that the extra feeds and fish wastes attached to the surface of Aquamat ${ }^{\mathrm{TM}}$, reduced TSS concentration in the water with culture system. The surface of Aquamat ${ }^{\mathrm{TM}}$ also provided places for microbes to grow and increased the nitrification process. The nitrification processes converted $\mathrm{NH}_{3}-\mathrm{N}$ to $\mathrm{NO}_{2}-\mathrm{N}$ then $\mathrm{NO}_{3}-\mathrm{N}$ with help from nitrifier bacteria and $\mathrm{DO}$ concentrations, which reduced $\mathrm{NH}_{3}-\mathrm{N}$ toxicity in the culture system. However, result also showed that the Aquamat ${ }^{\mathrm{TM}}$ increased the $\mathrm{NO}_{2}-\mathrm{N}_{\text {and }} \mathrm{NO}_{3}-\mathrm{N}$ concentrations in the culture system. This study suggests that the Aquamat ${ }^{\mathrm{TM}}$ is still not capable of eliminating the entire amount of dissolved inorganic nitrogen in the culture system for water quality management in a fish hatchery system.
\end{abstract}

Keywords: Ammonia; Nitrite; Nitrate; Geotextile; Water quality; Fish hatchery

\section{Introduction}

High quality water in sufficient volume is a primary consideration and a major factor in fish hatchery operations and management. It is generally agreed that high quality water is the most important input for aquaculture and thus a key element in the success of all phases of culture operations [1]. Slow growth and disease problems are generally linked to poor water quality. Deterioration in the quality of water increases stress on the captive animals, reduces their growth, makes them vulnerable to disease and can cause heavy mortality. Besides, water quality associated with aquaculture development is a matter of widespread concern since it can produce a variety of negative environmental impacts on the receiving environment [2].

Gaining insight into water quality helps aquaculture become more efficient and productive. Most importantly, it is the water quality that will influence optimal growth and yield. Water quality is defined as any characteristic of water in production systems that effect survival, reproduction, growth and production of aquaculture species. It also influences management decisions, causes environmental impacts, or reduces product quality and safety [3]. Many studies have reported the effects of water quality on the aquaculture organisms and environment [2-6]. Besides, several Water Quality Standards for Aquaculture Activity (WQSA) have been published to be used as a guideline [1,7-9]

No doubt, in order to keep the health of any aquaculture system at an optimal level, certain water quality parameters must be monitored and controlled. Water quality parameters outside the acceptable range will stress the fish in aquaculture systems. Therefore, it is equally important to know how to interpret the water quality parameters that are measured to maintain the health and well-being of the fish in aquaculture systems. While chemistry of water is a complex subject, most aspects of general importance to farmers can be simplified to allow for easier understanding and practical approaches to management. In our study, Estim [10] showed that high concentrations of $\mathrm{NH}_{3}-\mathrm{N}$ and $\mathrm{NO}_{3}-\mathrm{N}$ were recorded in the culture systems of Borneo Marine Research Institute (BMRI) Fish Hatchery of Universiti Malaysia Sabah, Malaysia (Figure 1). The $\mathrm{NH}_{3}-\mathrm{N}$ was higher in the daily exchange and flow-through culture systems where larvae and juveniles were stocked, while $\mathrm{NO}_{3}-\mathrm{N}$ was higher in the recirculating system used for stocking broodfish and in the waste water [11]. Those findings showed that some sections of the hatchery require attention for improvement, particularly the culture tanks and the waste water which recorded higher levels of $\mathrm{NH}_{3}-\mathrm{N}$ and $\mathrm{NO}_{3}-\mathrm{N}$. High concentration of ammonia can cause gill damage, reduce the oxygen carrying capacity of blood, increase the oxygen demand of tissues, damage red blood cells and affect osmoregulation $[7,8]$. $\mathrm{NO}_{3}$ is relatively non-toxic to aquatic organisms. However, it should not be left to accumulate because it eventually leads to some undesirable results such as phytoplankton blooms. In the marine waters of Sabah, $\mathrm{NO}_{3}-\mathrm{N}$ was reported to stimulate harmful algal bloom (Pyrodinium bahamense var compressum) even in a low concentration [10].

This paper provides information on Aquamat ${ }^{\mathrm{TM}}$, a biofilter application responsible for reducing dissolved inorganic nitrogen $\left(\mathrm{NH}_{3}-\mathrm{N}, \mathrm{NO}_{2}-\mathrm{N}\right.$ and $\left.\mathrm{NO}_{3}-\mathrm{N}\right)$ concentrations [12-14]. Aquamat ${ }^{\mathrm{TM}}$ is a new and innovative product fabricated from highly specialized synthetic polymer substrates. It forms a complex three-dimensional

*Corresponding author: Abentin Estim, Borneo Marine Research Institute Universiti Malaysia Sabah, 88999 Kota Kinabalu, Sabah, Jalan UMS, 88400 Kota Kinabalu, Sabah, Malaysia, Tel: +6088-320000; Fax: +6088-320261; E-mail: bentin@ums.edu.my

Received April 29, 2014; Accepted June 26, 2014; Published July 07, 2014

Citation: Estim A, Mustafa S (2014) Water Quality Remediation Using Geotextile in Fish Hatchery Systems. J Aquac Res Development 5: 244 doi:10.4172/21559546.1000244

Copyright: ( 2014 Estim A, et al. This is an open-access article distributed under the terms of the Creative Commons Attribution License, which permits unrestricted use, distribution, and reproduction in any medium, provided the original author and source are credited. 


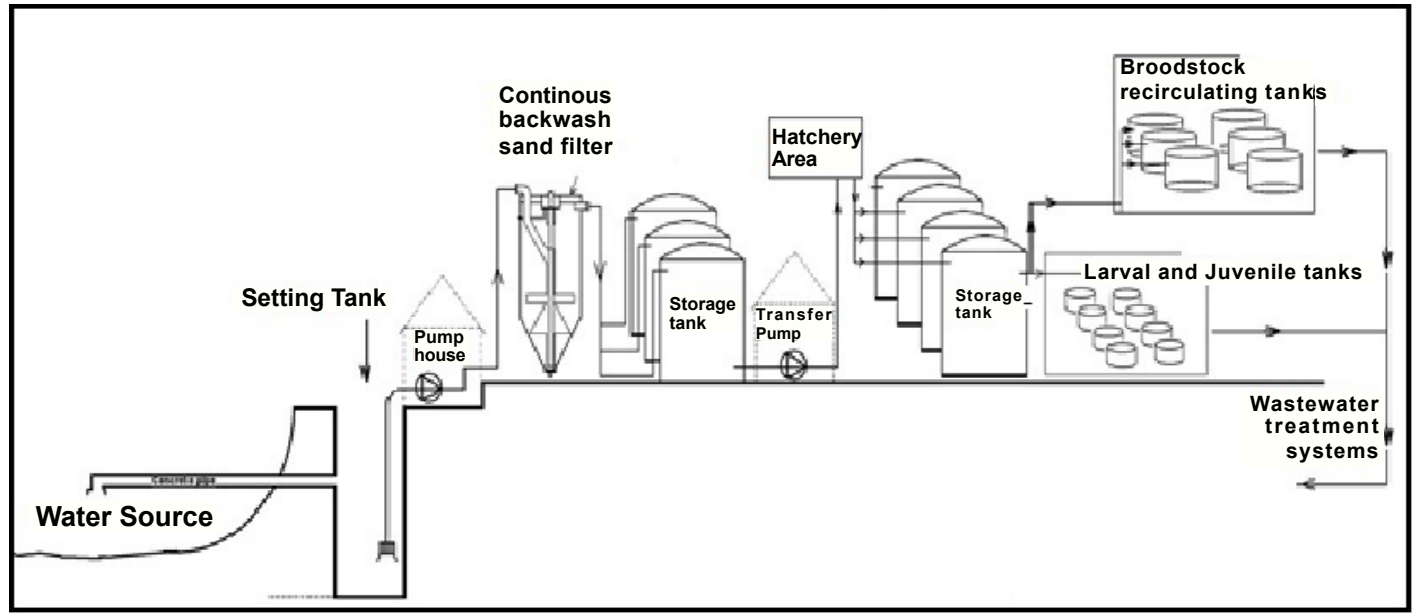

Figure 1: Layout of the Borneo Marine Research Institute Fish Hatchery Water Systems of Universiti Malaysia Sabah, Malaysia

structure, resembling seagrass in appearance; provide aquatic habitat, in situ biofiltration and water renovation while the culture is under progress. This media has been principally used to support high stocking densities in fish culture ponds [14] and enhancing biological processes in ornamental ponds [12] and observed decrease in $\mathrm{NH}_{3}-\mathrm{N}$ levels to treat shrimp farm waste water [13] (Figure 1).

\section{Materials and Methods}

\section{Daily exchange system}

Six circular fiberglass tanks of $1000 \mathrm{~L}$ were used for the experiment. Three tanks were equipped with Aquamat ${ }^{\mathrm{TM}}$ while the other three were no Aquamat ${ }^{\mathrm{TM}}$. Each Aquamat ${ }^{\mathrm{TM}}$ has a surface area of $31.28 \mathrm{~m}^{2}$. The total biomass of seabass, Lates calcarifer, juvenile stocked in each tank was $120 \mathrm{~g}$ (fish mean weight, $0.156 \pm 0.1 \mathrm{~g}$ ), $130 \mathrm{~g}$ (fish mean weight, $0.219 \pm 0.1 \mathrm{~g}$ ) and $150 \mathrm{~g}$ (fish mean weight, $0.602 \pm 0.1 \mathrm{~g}$ ) for the $1^{\text {st }}$, $2^{\text {nd }}$ and $3^{\text {rd }}$ of 10 days, respectively. During the experiment, $20 \%$ of KINTARO formulated feed (protein, $38.8 \%$; lipid, 9.82\%; moist, 10.71 $\%$; ash, $11.48 \%$ and fiber, $23.13 \%$ ) was given twice daily, in the morning (9:00) and afternoon (16:00). The seawater of each culture tank was changed 0-70 \% per day.

\section{Flow-through system}

Four $2000 \mathrm{~L}$ rectangular fiberglass tanks were used for the experiment. Two tanks were stocked with 44 tails of seabass juvenile (mean body weight, $254.7 \pm 74.0 \mathrm{~g}$ ). Another two were stocked with 40 tails of tiger grouper, Epinephelus lanceolatus (mean body weight, $346.9 \pm 61.7 \mathrm{~g}$ ). One tank each of L. calcarifer and E. lanceolatus tanks was provided with two Aquamat ${ }^{\mathrm{TM}}$. Each Aquamat ${ }^{\mathrm{TM}}$ has surface area of $31.28 \mathrm{~m}^{2}$. The seawater flow rate was maintained $15-25 \mathrm{~L} / \mathrm{min}$ in each culture tank.

\section{Water quality analyses}

Seawater temperature, $\mathrm{pH}$, dissolved oxygen (DO) and salinity of culture tanks were recorded daily between 8.30 am to 11.00 am using data logger $\left(\right.$ Cyberscan $\left.{ }^{\mathrm{TM}}\right)$. The seawater samples $(500 \mathrm{~mL})$ from each tank were collected on a daily basis and filtered through membrane filter $(0.45 \mu \mathrm{m})$, then brought to the laboratory for further analyses. Methods described by Parsons et al. [15] were used to determine total suspended solids (TSS) and dissolved inorganic nitrogen namely, ammonia $\left(\mathrm{NH}_{3}-\mathrm{N}\right)$, nitrite $\left(\mathrm{NO}_{2}-\mathrm{N}\right)$ and nitrate $\left(\mathrm{NO}_{3}-\mathrm{N}\right)$.

\section{Bacteria colony count $(\mathrm{CFU} / \mathrm{mL})$}

Seawater samples were collected from each culture tank using a universal bottle of $10 \mathrm{~mL}$. Solid samples from the surface area of $1 \mathrm{~cm}^{2}$ of Aquamat ${ }^{\mathrm{TM}}$ were also collected using sterile cotton bud, and then put into a universal bottle of $10 \mathrm{~mL}$ sterile seawater. The sterile seawater was filtered using $0.45 \mu \mathrm{m}$ membrane filter, and then autoclaved. Seawater and solid samples were collected at day 10 of the experiment, then immediately brought to the laboratory for further analyses. Serial dilutions of samples were prepared at $10^{-3}, 10^{-4}$ and $10^{-5}$. Samples of 0.1 $\mathrm{mL}$ were inoculated onto triplicate sets of marine agar media (Difco).

\section{Statistical analyses}

Independent Samples T-test and One way analyses of variance (ANOVA, $\mathrm{p}=0.05$ ) were used to detect differences in the water quality $\left(\mathrm{NH}_{3}-\mathrm{N}, \mathrm{NO}_{2}-\mathrm{N}, \mathrm{NO}_{3}-\mathrm{N}\right.$, temperature, $\mathrm{pH}, \mathrm{DO}$ and salinity) between culture systems with and without Aquamat ${ }^{\mathrm{TM}}$. All the tests were conducted after the confirmation of homogeneity of variance (Levene's test). To satisfy the assumptions of normality and homogeneity of variance, data on the $\mathrm{NH}_{3}-\mathrm{N}$ of daily exchange system and $\mathrm{CFU} / \mathrm{mL}$ bacteria colony were transformed by $\log _{10}$ to achieve homogenous data.

\section{Results}

Average values of temperature, $\mathrm{DO}, \mathrm{pH}$ and salinity in the culture tanks with and without Aquamat ${ }^{\mathrm{TM}}$ for the daily exchange system for L. calcarifer are shown in the Table 1 . It is evident from the data that the mean temperature ranged from $27.69 \pm 0.35$ to $28.09 \pm 0.43^{\circ} \mathrm{C}, \mathrm{DO}$ ranged from $5.74 \pm 0.17$ to $5.94 \pm 0.23 \mathrm{mg} / \mathrm{L}, \mathrm{pH}$ ranged from $7.66 \pm$ 0.12 to $7.81 \pm 0.12$ and salinity varied from $19.27 \pm 0.63$ to $20.33 \pm 0.62$ psu. Independent Samples T-test proved that the DO in culture tanks with and without Aquamat ${ }^{\mathrm{TM}}$ was significantly difference $(\mathrm{F}=25.085$; $\mathrm{t}=-2.833 ; \mathrm{P}=0.005)$, but no significant different for temperature $(\mathrm{F}=0.177 ; \mathrm{t}=-0.182 ; \mathrm{P}=0.856), \mathrm{pH}(\mathrm{F}=0.264 ; \mathrm{t}=-0.417 ; \mathrm{P}=0.677)$ and salinity $(\mathrm{F}=3.956 ; \mathrm{t}=0.343 ; \mathrm{P}=0.732)$.

Table 2 shows mean ( \pm S.D.) of temperature, $\mathrm{DO}$ and $\mathrm{pH}$ in the culture tanks with and without Aquamat ${ }^{\mathrm{TM}}$ for the flow-through systems for $L$. calcarifer and E. lanceolatus juveniles. It showed that the mean temperature ranged from $27.92 \pm 0.53$ to $28.22 \pm 0.58^{\circ} \mathrm{C}$, DO varied from $6.06 \pm 0.49$ to $6.42 \pm 0.41 \mathrm{mg} / \mathrm{L}$ and $\mathrm{pH}$ was in the range of $7.95 \pm 0.56$ to $8.14 \pm 0.28$. Independent samples test indicated that 


\begin{tabular}{|c|c|c|c|c|c|}
\hline & & Added & $1^{\text {st }}$ Period & $2^{\text {nd }}$ Period & $3^{\text {rd }}$ Period \\
\hline & $\mathrm{N}$ & Aquamat & $(10$ days $)$ & $(10$ days $)$ & $(10$ days $)$ \\
\hline $\begin{array}{c}\text { Temperature } \\
\left({ }^{\circ} \mathrm{C}\right)\end{array}$ & 24 & No & $27.69 \pm 0.35$ & $27.78 \pm 0.28$ & $28.09 \pm 0.43$ \\
\hline & 24 & Yes & $27.70 \pm 0.34$ & $27.81 \pm 0.26$ & $28.04 \pm 0.44$ \\
\hline $\mathrm{DO}(\mathrm{mg} / \mathrm{L})$ & 24 & No & $5.84 \pm 0.25^{\mathrm{a}}$ & $5.94 \pm 0.23^{\mathrm{a}}$ & $5.85 \pm 0.13^{\mathrm{a}}$ \\
\hline & 24 & Yes & $5.75 \pm 0.20^{\mathrm{b}}$ & $5.78 \pm 0.23^{\mathrm{b}}$ & $5.74 \pm 0.17^{\mathrm{b}}$ \\
\hline $\mathrm{pH}$ & 24 & No & $7.74 \pm 0.14$ & $7.66 \pm 0.12$ & $7.81 \pm 0.12$ \\
\hline & 24 & Yes & $7.70 \pm 0.15$ & $7.80 \pm 0.15$ & $7.78 \pm 0.15$ \\
\hline Salinity (ppt) & 24 & No & $19.32 \pm 0.57$ & $19.52 \pm 0.62$ & $20.17 \pm 0.70$ \\
\hline & 24 & Yes & $19.27 \pm 0.63$ & $19.47 \pm 0.56$ & $20.33 \pm 0.62$ \\
\hline $\begin{array}{c}\text { Fish biomass } \\
\text { gain (g) }\end{array}$ & 3 & No (Initial) & 120.00 & 130.00 & 150.00 \\
\hline & & No (Final) & $165.05 \pm 14.98$ & $140.03 \pm 4.91$ & $163.39 \pm 7.67$ \\
\hline & & Yes (Initial) & 120.00 & 130.00 & 150.00 \\
\hline Yes (Final) & $183.35 \pm 16.05$ & $181.61 \pm 5.82$ & $226.61 \pm 12.67$ \\
\hline $\begin{array}{c}\text { Survival Rate } \\
(\%)\end{array}$ & 3 & No & $76.72 \pm 6.96$ & $67.52 \pm 2.37$ & $60.71 \pm 2.95$ \\
\hline & & Yes & $85.23 \pm 7.46$ & $87.57 \pm 2.81$ & $84.20 \pm 4.88$ \\
\hline
\end{tabular}

Values with different superscripts within row are significantly different $(P<0.05)$

Table 1: Temperature, $\mathrm{DO}, \mathrm{pH}$, salinity, fish biomass gain and survival rate in the daily exchange culture systems with and without Aquamat ${ }^{\mathrm{TM}}$. Values are mean \pm SD.

\begin{tabular}{|l|c|c|c|c|}
\hline & & & \multicolumn{2}{|c|}{ Added Aquamat } \\
\hline & $\mathrm{N}$ & Fish cultured & No & Yes \\
\hline Temperature $\left({ }^{\circ} \mathrm{C}\right)$ & 16 & L. calcarifer & $27.92 \pm 0.53$ & $28.22 \pm 0.58$ \\
\hline & 16 & E. lanceolatus & $28.21 \pm 0.74$ & $28.21 \pm 0.63$ \\
\hline $\mathrm{DO}(\mathrm{mg} / \mathrm{L})$ & 16 & L. calcarifer & $6.42 \pm 0.41$ & $6.06 \pm 0.49$ \\
\hline & 16 & E. lanceolatus & $6.37 \pm 0.38$ & $6.33 \pm 0.32$ \\
\hline $\mathrm{pH}$ & 16 & L. calcarifer & $8.14 \pm 0.22$ & $8.14 \pm 0.28$ \\
\hline & 16 & E. lanceolatus & $7.95 \pm 0.56$ & $8.06 \pm 0.33$ \\
\hline $\mathrm{NH}_{3}-\mathrm{N}(\mathrm{mg} / \mathrm{L})$ & 16 & L. calcarifer & $0.57 \pm 0.23$ & $0.50 \pm 0.18$ \\
\hline & 16 & E. lanceolatus & $0.64 \pm 0.24$ & $0.58 \pm 0.21$ \\
\hline $\mathrm{NO}_{2}-\mathrm{N}(\mu \mathrm{g} / \mathrm{L})$ & 16 & L. calcarifer & $0.43 \pm 0.41$ & $0.43 \pm 0.45$ \\
\hline & 16 & E. lanceolatus & $0.46 \pm 0.36$ & $0.44 \pm 0.36$ \\
\hline $\mathrm{NO}_{3}-\mathrm{N}(\mathrm{mg} / \mathrm{L})$ & 16 & L. calcarifer & $12.88 \pm 9.27$ & $16.96 \pm 12.46$ \\
\hline & 16 & E. lanceolatus & $12.16 \pm 7.63$ & $17.44 \pm 12.96$ \\
\hline $\begin{array}{l}\text { Specific growth rate } \\
(\% \text { per day) }\end{array}$ & 44 tails & L. calcarifer & $1.20 \pm 0.16$ & $1.43 \pm 0.16$ \\
\cline { 2 - 5 } & 40 tails & E. lanceolatus & $0.27 \pm 0.03$ & $0.50 \pm 0.04$ \\
\hline
\end{tabular}

Salinity was maintained at 29-31 ppt (recorded using refractometer).

Table 2: Temperature, $\mathrm{DO}, \mathrm{pH}, \mathrm{NH}_{3}-\mathrm{N}, \mathrm{NO}_{2}-\mathrm{N}, \mathrm{NO}_{3}-\mathrm{N}$ and fish specific growth rate in flow-through culture system with and without Aquamat ${ }^{\mathrm{TM}}$. Values are mean $\pm \mathrm{SD}$.

the temperature, $\mathrm{DO}$ and $\mathrm{pH}$ in the culture tanks with and without Aquamat ${ }^{\mathrm{TM}}$ were not significantly different $(\mathrm{p}>0.05)$ (Tables 1 and 2$)$.

\section{Dissolved Inorganic Nitrogen}

Figure 2 shows mean $( \pm \mathrm{SD})$ of $\mathrm{NH}_{3}-\mathrm{N}, \mathrm{NO}_{2}-\mathrm{N}, \mathrm{NO}_{3}-\mathrm{N}$ and TSS in the culture tanks with and without Aquamat ${ }^{\mathrm{TM}}$ for the daily exchange system. The mean values of $\mathrm{NH}_{3}-\mathrm{N}(\mathrm{F}=0.028 ; \mathrm{t}=-2.006 ; \mathrm{P}=0.047)$ and TSS $(\mathrm{F}=1.144 ; \mathrm{t}=-2.787 ; \mathrm{P}=0.006)$ were significantly lower in the culture tanks with Aquamat ${ }^{\mathrm{TM}}$ than the culture tanks without Aquamat ${ }^{\mathrm{TM}}$. For the $\mathrm{NO}_{2}-\mathrm{N}(\mathrm{F}=0.884 ; \mathrm{t}=0.487 ; \mathrm{P}=0.627)$ and $\mathrm{NO}_{3}-\mathrm{N}(\mathrm{F}=1.887$; $\mathrm{t}=1.390 ; \mathrm{P}=0.167)$ concentrations, there was no significant difference. These results indicated that the Aquamat ${ }^{\mathrm{TM}}$ could reduce $\mathrm{NH}_{3}-\mathrm{N}$ and TSS concentrations in the daily exchange system. Table 2 shows mean ( \pm S.D.) concentration of $\mathrm{NH}_{3}-\mathrm{N}, \mathrm{NO}_{2}-\mathrm{N}$ and $\mathrm{NO}_{3}-\mathrm{N}$ in the culture tanks with and without Aquamat ${ }^{\mathrm{TM}}$ for the flow-through system for $L$. calcarifer and E. lanceolatus juveniles. It is obvious from the data that the mean $\mathrm{NH}_{3}-\mathrm{N}$ ranged from $0.50 \pm 0.18$ to $0.64 \pm 0.24 \mathrm{mg} / \mathrm{L}, \mathrm{NO}_{2}-\mathrm{N}$ varied from $0.43 \pm 0.0 .45$ to $0.46 \pm 0.0 .360 \mu \mathrm{g} / \mathrm{L}$ and $\mathrm{NO}_{3}-\mathrm{N}$ was in the range of $12.16 \pm 7.63$ to $17.44 \pm 12.96 \mathrm{mg} / \mathrm{L}$. Independent Samples Test indicated that the concentrations of $\mathrm{NH}_{3}-\mathrm{N}(\mathrm{F}=3.124 ; \mathrm{t}=1.206$; $\mathrm{P}=0.232), \mathrm{NO}_{2}-\mathrm{N}(\mathrm{F}=3.118 ; \mathrm{t}=-0.198 ; \mathrm{P}=0.844)$ and $\mathrm{NO}_{3}-\mathrm{N}(\mathrm{F}=3.685$; $\mathrm{t}=-1.761 ; \mathrm{P}=0.083$ ) of the culture tanks with and without Aquamat were not significantly different (Figure 2).

\section{Fish biomass and growth}

Table 1 shows the fish biomass gains were significantly higher in the culture tank with Aquamat ${ }^{\mathrm{TM}}$ than in the culture tank without Aquamat $^{\mathrm{TM}}(\mathrm{F}=2.177 ; \mathrm{t}=-4.296 ; \mathrm{P}=0.001)$. The mean $( \pm \mathrm{SD})$ of fish biomass gains were $52.79 \pm 13.39 \mathrm{~g}, 39.70 \pm 4.44 \mathrm{~g}$ and $51.07 \pm 8.39 \mathrm{~g}$, for the $1^{\text {st }}, 2^{\text {nd }}$ and $3^{\text {rd }}$ of 10 days, respectively, in the culture tank with Aquamat $^{\mathrm{TM}}$ compared to $37.54 \pm 12.50 \mathrm{~g}, 7.72 \pm 3.84 \mathrm{~g}$ and $8.93 \pm 5.11$ $\mathrm{g}$, respectively for the culture tank without Aquamat ${ }^{\mathrm{TM}}$. For the flowthrough system, the weight gains in $L$. calcarifer $(\mathrm{F}=; \mathrm{t}=-; \mathrm{P}=0.0)$ and E. lanceolatus $(\mathrm{F}=; \mathrm{t}=-; \mathrm{P}=0.0)$ were not significantly different between the culture tanks with and without Aquamat ${ }^{\mathrm{TM}}$ (Table 2). The specific growth rate of $L$. calcarifer and E. lanceolatus in the culture tank with Aquamat ${ }^{\mathrm{TM}}$ was $1.43 \pm 0.16 \%$ perday and $0.50 \pm 0.04 \%$ perday, respectively and in the culture tank without Aquamat ${ }^{\mathrm{TM}}$ it was $1.20 \pm$ $0.04 \%$ perday and $0.27 \pm 0.03 \%$ per day, respectively.

\section{Bacteria colony $(\mathrm{CFU} / \mathrm{ml})$}

Colonies of bacteria in the seawater of culture tanks with and without Aquamat ${ }^{\mathrm{TM}}$ were significantly different $(\mathrm{F}=11.437 ; \mathrm{df}=2$; $\mathrm{P}=0.000)$ compared to the bacterial colony on the surface of Aquamat ${ }^{\mathrm{TM}}$ (Figure 3). The bacterial colony average for the entire experiment was $1.20 \times 10^{6} \pm 0.26 \mathrm{CFU} / \mathrm{mL}$ in the seawater without Aquamat ${ }^{\mathrm{TM}}, 1.77 \times 10^{6}$ $\pm 0.56 \mathrm{CFU} / \mathrm{mL}$ in the seawater with Aquamat ${ }^{\mathrm{TM}}$ and $8.11 \times 10^{6} \pm 4.95$ $\mathrm{CFU} / \mathrm{mL}$ on the surface of Aquamat ${ }^{\mathrm{TM}}$. Table 3 shows 12 different bacterial colonies that were isolated from the culture systems with and without Aquamat ${ }^{\mathrm{TM}}$ and on the surface of Aquamat ${ }^{\mathrm{TM}}$, which consisted of 4 gram positive and 8 gram negative types. Table 4 shows results of the biochemical test of 12 major colonies (Figure 3) (Tables 3 and 4).

\section{Discussion}

Results obtained from the present trials indicated that the use of Aquamat ${ }^{\mathrm{TM}}$ in the daily exchange culture system improved the fish biomass gain and the survival rate. Besides, it also reduced the $\mathrm{NH}_{3}-\mathrm{N}$ and TSS concentrations. These findings are consistent with the outcome of the research published earlier $[13,16,17]$. These authors explained that the use of artificial substrates improved the production and water quality. However, Aquamat ${ }^{\mathrm{TM}}$ was not shown to produce

\begin{tabular}{|l|c|l|}
\hline Colony & Gram & $\begin{array}{l}\text { Characteristics (colour, colony periphery, configuration and colony } \\
\text { elevation) }\end{array}$ \\
\hline T1 & + & Reddish-brown, smooth, round and flat \\
\hline T2 & - & Yellow, smooth, round and umbonate \\
\hline T3 & - & Yellowish-orange, smooth, round and penetrate intomedium \\
\hline T4 & - & White, wavy, round and umbonate \\
\hline T5 & - & Yellow, wavy, round, flat \\
\hline T6 & - & White, smooth, round and penetrate into medium \\
\hline T7 & + & Yellowish-white, wavy, round and umbonate \\
\hline T8 & - & Yellowish-white, wavy, round and umbonate \\
\hline T9 & + & Pink, wavy, round and penetrate into medium \\
\hline T10 & - & Reddish brown, smooth, round and penetrate into medium \\
\hline T11 & + & Yellow, smooth, round and penetrate into medium \\
\hline T12 & - & Yelloowish white, smooth, round and flat \\
\hline
\end{tabular}

Table 3: Twelve types of bacteria colonies isolated from the seawater of culture tanks and on the surface of Aquamat ${ }^{\mathrm{TM}}$. 

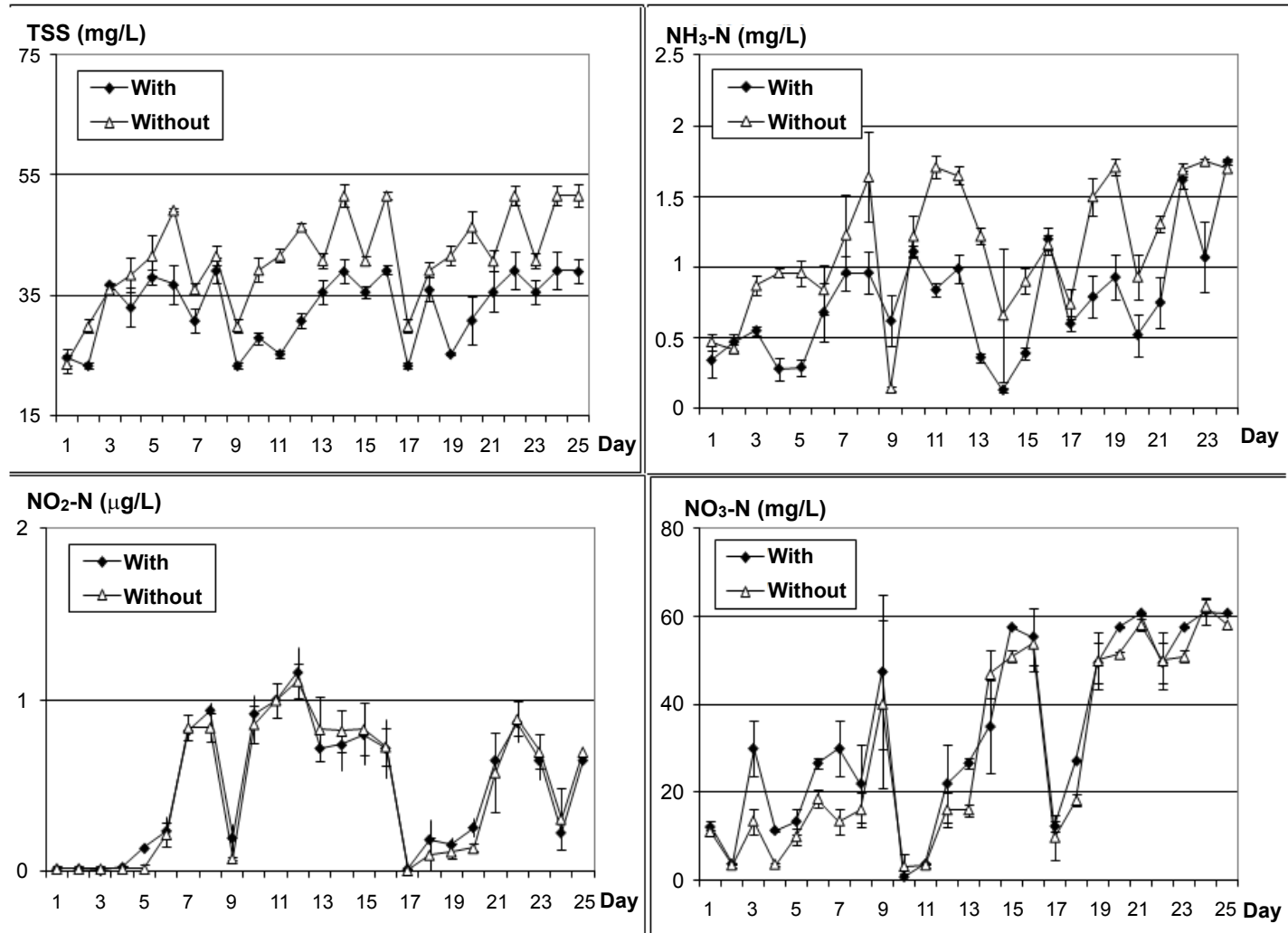

Figure 2: Concentrations of TSS, $\mathrm{NH}_{3}-\mathrm{N}, \mathrm{NO}_{2}-\mathrm{N}$, and $\mathrm{NO}_{3}-\mathrm{N}$ in the daily exchange of $L$. calcariferivenile culture systems with and without Aquamat ${ }^{\mathrm{TM}}$. Values are mean $\pm \mathrm{SD}$.

any appreciable effect on the flow-through culture system for $L$. calcarifer and E. lanceolatus juveniles. This finding is concurrent with the observation of kumlu et al. [5] which reported that the artificial substrates do not provide any advantage during the post-larvae culture.

The experiment on daily exchange showed that the $\mathrm{NH}_{3}-\mathrm{N}$ mean concentration in the culture tanks of with Aquamat ${ }^{\mathrm{TM}}$ was significantly $(\mathrm{p}<0.05)$ lower than in the culture tanks without Aquamat ${ }^{\mathrm{TM}}$, except for the first 6 days. It seems that the mineralization process of protein occurred faster in the culture tank with Aquamat ${ }^{\mathrm{TM}}$ than in the culture tank without Aquamat ${ }^{\mathrm{TM}}$ for the first of 6 days. Possibly, the decomposition of organic matter in the surrounding water leads to increase in $\mathrm{NH}_{3}$ and $\mathrm{NO}_{2}$ concentrations [18]. The autotrophic organisms mineralized waste feed and feces resulting in different dissolved nitrogen fractions [4].

Fish biomass gains in the culture tanks with Aquamat ${ }^{\mathrm{TM}}$ were significantly $(\mathrm{p}<0.05)$ higher than in the culture tanks without Aquamat ${ }^{\mathrm{TM}}$. Cannibalism and high $\mathrm{NH}_{3}-\mathrm{N}$ and TSS concentrations in the culture tanks without Aquamat ${ }^{\mathrm{TM}}$ caused high mortality. Kailasam et al. [19] reported that the seabass is a highly predatory fish and differential growth among the larvae during rearing can lead to cannibalism, resulting in poor survival rate. Besides, the surface area of Aquamat ${ }^{\mathrm{TM}}$ provides places for fish to hide and to protect them from cannibalism activity. From the present observation, it is evident that the feed-particles were attached to the surface of Aquamat ${ }^{\mathrm{TM}}$, which would supply diets at any time. Moss and Moss [20] reported that shrimp growth increased in the presence of substrates due to the availability of attached particulate organic matter as well as by the use of artificial substrates. Bratvold and Browdy [13] reported that artificial substrate increases the nitrification in culture tanks, which causes decline in the concentrations of ammonia. Use of Aquamat ${ }^{\mathrm{TM}}$ would help to enhance nitrification process and reduce the toxicity due to $\mathrm{NH}_{3}-\mathrm{N}$. In a nitrification process, $\mathrm{NH}_{3}-\mathrm{N}$ is first oxidized into nitrite then into nitrate by several genera of bacteria [18]. Aquamat ${ }^{\mathrm{TM}}$ provides surface area for microbes to grow and enhance the nitrification process. Increase in available surface area in the oxygenated water column may also promote growth of specific bacterial groups such as nitrifiers, which are more likely to inhabit surfaces than the freefloating forms [21]. The recent availability of products for increasing vertical surfaces in aquaculture systems has raised interest in the effects of vertical surface enhancement by placement of many flexible curtains throughout the water column [13]. The most obvious effect of vertical surface enhancement is the potential shift of the major site of primary production especially microbs. As shown in Figure 3, the bacterial colonies were higher on the surface of Aquamat ${ }^{\mathrm{TM}}$ than in the water. Table 3 and 4 summarizes the results of biochemical test of twelve major bacterial colonies, which consisted of 4 gram positive and 8 gram negative types. Colonies of bacteria in the seawater of culture tanks with and without Aquamat ${ }^{\mathrm{TM}}$ were significantly different $(\mathrm{p}<0.05)$ compared to the bacterial colony on the surface of Aquamat ${ }^{\mathrm{TM}}$ (Figure 3).

The Aquamat ${ }^{\mathrm{TM}}$ provides aquatic habitat, and in situ biofiltration and water remediation facility while the culture is under progress. This product has been principally used to support high stocking densities in fish culture ponds [14] and enhancing biological processes in ornamental ponds $[12,13]$ observed decrease in $\mathrm{NH}_{3}-\mathrm{N}$ levels using the Aquamat ${ }^{\mathrm{TM}}$ and sand sediment to treat shrimp farm waste water. 


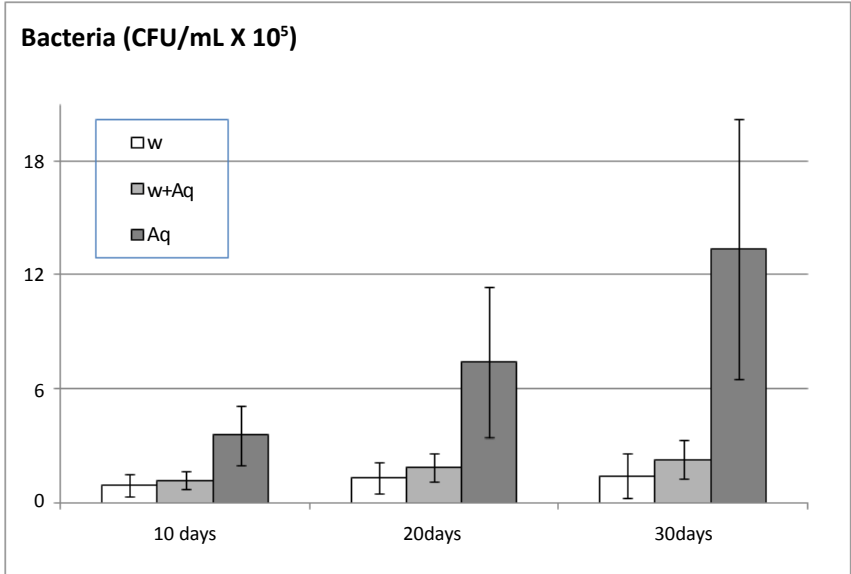

Figure 3: Bacterial colony $(\mathrm{CFU} / \mathrm{mL})$ on the surface of Aquamat ${ }^{\mathrm{TM}}$ and in the seawater of culture tanks with and without Aquamat ${ }^{\mathrm{TM}}$ during the experimental period. Values are means \pm SD

\begin{tabular}{|c|c|c|c|c|c|c|c|c|c|c|c|c|}
\hline & T1 & T2 & T3 & T4 & T5 & T6 & T7 & T8 & T9 & T10 & T11 & T12 \\
\hline Gram & + & - & - & - & - & - & + & - & + & - & + & - \\
\hline Shape & $\mathrm{R}$ & $R$ & $S$ & $R$ & $\mathrm{R}$ & $\mathrm{R}$ & S & $\mathrm{R}$ & $S$ & $\mathrm{R}$ & $\mathrm{R}$ & S \\
\hline Motility & - & + & - & + & + & + & + & + & - & + & - & - \\
\hline Catalase & + & + & + & + & + & + & + & + & + & + & + & + \\
\hline Oxidase & - & + & - & - & + & - & - & + & - & + & - & - \\
\hline Glucose (acid) & - & + & + & - & - & + & + & + & - & - & - & - \\
\hline Carbohydrates (O/F/-) & - & $\mathrm{F}$ & 0 & 0 & 0 & $\mathrm{~F}$ & $\mathrm{~F}$ & 0 & $0 /-$ & 0 & - & $0 /-$ \\
\hline Mannitol & - & & & - & - & - & - & & - & - & - & \\
\hline Lactose & - & - & + & - & - & - & - & - & - & - & - & - \\
\hline Maltose & - & D & D & + & - & + & + & D & - & - & - & - \\
\hline Trehalose & & & & & & & & $\mathrm{D}$ & & & - & \\
\hline Xylose & - & & + & - & - & + & + & + & - & - & - & - \\
\hline Sucrose & - & D & + & - & - & + & + & - & - & - & - & + \\
\hline Glyserol & & & & & & & - & & & & & \\
\hline Raffinose & & & & & & & - & & & & & \\
\hline Sorbitol & & & & & & & - & & & & & \\
\hline VP & - & - & & & & + & & & - & & - & \\
\hline Indol & - & - & - & - & - & + & - & - & - & - & - & - \\
\hline Gelatin hydrolysis & - & - & D & - & - & - & - & - & - & - & - & - \\
\hline Ornithin Decarboxylase & + & + & + & + & + & - & + & - & + & + & + & + \\
\hline Urease & + & & D & + & - & + & + & $\mathrm{D}$ & $\mathrm{D}$ & - & + & - \\
\hline $\mathrm{H} 2 \mathrm{~S}$ & + & + & + & + & + & + & + & + & - & - & - & + \\
\hline Growth at $42 \mathrm{oC}$ & & & + & + & + & - & - & - & & + & & + \\
\hline Growth at $37 \mathrm{oC}$ & + & - & & & & & & & & & & \\
\hline Growth - SS Agar & & & & + & + & + & & & & + & & \\
\hline Growth on MacConkey & & & + & + & + & + & & + & & + & & + \\
\hline Growth without $\mathrm{NaCl}$ & & + & & & & - & & & & & & \\
\hline Growth- $6 \% \mathrm{NaCl}$ & & & & & & + & - & & & & & \\
\hline Growth on KCN & & - & & + & + & & & - & & - & & \\
\hline
\end{tabular}

$\mathrm{D}=$ Different reactions; $\mathrm{F}=$ Fermentative $\mathrm{O}=$ Oxidative $\mathrm{R}=$ Rod-shape $; \mathrm{S}=$ Sphere or Coccus

Table 4: Results of biochemical test on 12 major bacterial colonies isolated in the seawater of culture systems with and without Aquamat ${ }^{\mathrm{TM}}$, and on the surface of Aquamat $^{\mathrm{TM}}$
There are two types of Aquamats such as SDF (surface deployment filter) and BDF (bottom deployment filters). Such geotextile products have become quite popular in aquaculture and other water treatment operations. Hargreaves [22] explained that nutrient cycling and related water quality are significantly affected by the sediment community. He described in detail the suspended growth systems in aquaculture, which depends on an active mass of phytoplankton, free and attached bacteria, aggregates of living and dead particulate organic matter, and microbial grazer that is maintained in suspension. These systems have been described using a wide variety of terms, most emphasizing the role of bacterial processes. In suspended-growth systems, substrates are typically mixed with suspended microbes in rearing units and in the attached-growth systems, substrates are transported from rearing units to specialized reactors performing a specific unit operation in a treatment chain [22].

Obviously, an increase in aquaculture surface area has the potential to result in a plethora of changes in the microbial community [13]. Evaluation of geotextile filtration applying coagulant and flocculant amendments for aquaculture biosolids dewatering and phosphorus removal has been done by Sharrer et al. [6]. Bratvold and Browdy [13] elaborated that the potentially positive and negative chemical and biological effects of sediment bottom surfaces may also be seen on vertical surfaces. The recent availability of products for increasing vertical surfaces in aquaculture systems has raised interest in the effects of vertical surface enhancement by placement of many flexible curtains throughout the water column. Schneider et al. [24], explained that nutrients are not re-used, they are in fact destroyed and discharged in a harmless form by nitrification, denitrification and heterotrophic degradation. Although these kinds of processes successfully decrease the amount of discharged nutrients, such systems do not increase the retention of nutrients. Instead of destructing and or volatilizing or storing nutrients, nutrients can also be converted into bacteria biomass and re-used as single cell protein (SCP). Henze et al. [23], added that if carbon and nitrogen are well balanced in the bacterial substrate, ammonia in addition to organic nitrogenous waste will be converted into bacteria biomass. This conversion is an additional sink for ammonia and contributes to dissolve waste conversion [24].

Results also indicated that the Aquamat ${ }^{\mathrm{TM}}$ could reduce TSS concentration in the daily exchange system. Stewart et al. [16] reported that the TSS removal increased when Aquamat ${ }^{\mathrm{TM}}$ biofiltration media were installed in a first section of sedimentation basin. High TSS concentrations tend to clog fish gills which may lead to mortality, affect the gill epithelial tissues and facilitate the disease such as fin rot which is caused by mycobacteria. This limits the ability of fish to find food, increases susceptibility to predators and to gill abrasion [7]. Sharrer et al. [6] concluded that geotextile, a woven and porous polyethylene material can consistently remove approximately $95 \%$ of the TSS contained in aquaculture backwash flows when loaded at approximately $60-70 \mathrm{~L} / \mathrm{day} / \mathrm{m}^{2}$ bag surface area. Geotextile bag filters provide good solids dewatering and producing $19-22 \%$ biosolids concentrations.

Result also showed that the Aquamat ${ }^{\mathrm{TM}}$ would increase $\mathrm{NO}_{2}-\mathrm{N}$ and $\mathrm{NO}_{3}-\mathrm{N}$ concentrations and decrease the DO concentrations in the culture system. It was apparent that the mean value of $\mathrm{NO}_{2}-\mathrm{N}$ and $\mathrm{NO}_{3}-\mathrm{N}$ were slightly higher in the culture tanks with Aquamat ${ }^{\mathrm{TM}}$ than without Aquamat ${ }^{\mathrm{TM}}$. ASEAN Marine Water Quality Criteria suggests that the $\mathrm{NO}_{3}-\mathrm{N}$ for aquatic life protection is not more $60 \mu \mathrm{g} / \mathrm{L}$, and although in a low concentration, $\mathrm{NO}_{3}-\mathrm{N}$ could stimulate harmful algal bloom (Pyrodinium bahamense var compressum) in the marine waters 
of Sabah [10]. DO concentration was significantly lower $(\mathrm{p}<0.05)$ in the culture tanks with Aquamat ${ }^{\mathrm{TM}}$ than those without Aquamat ${ }^{\mathrm{TM}}$ because of the nitrification process. The reactions of nitrification require oxygen to produce hydrogen ions and nitrite as an intermediate product, then to the nitrate by involvement of bacteria such as Nitrosomonas sp and Nitrobacter $s p$. Schneider et al., [24], elaborated that several factors, such as micro-, and macronutrient ratios, concentrations and fluxes, preferences for nitrogen sources, light regime, hydraulic retention time, temperature, and nutrient loss to different sinks will strongly determine the success of phototrophic production. The excessively available nutrient is released unconverted from the module and accumulates in the culture system, and needs finally to be discharged into the environment. This might result in limitations of the desired conversion processes, because effluent streams from the fish can then not be treated continuously anymore [24].

\section{Conclusion}

Aquamat $^{\mathrm{TM}}$ improved the water quality in the daily exchange culture system. It could reduce fish mortality and $\mathrm{NH}_{3}-\mathrm{N}$ and TSS concentrations. The Aquamat ${ }^{\mathrm{TM}}$ provided surface area for larval fish to hide from cannibalism activity, for attachment of extra feed ingredients and fish waste, and for microbes to grow, which enhance nitrification process. In this process of nitrification, $\mathrm{NH}_{3}-\mathrm{N}$ was converted to $\mathrm{NO}_{2}-\mathrm{N}$ then to the $\mathrm{NO}_{3}-\mathrm{N}$ with the role played by nitrifier bacteria and $\mathrm{DO}$ concentration. This resulted in reduced $\mathrm{NH}_{3}-\mathrm{N}$ toxicity in the culture system. However, the study also showed that $\mathrm{NO}_{2}-\mathrm{N}$ and $\mathrm{NO}_{3}-\mathrm{N}$ concentrations will be higher in the culture system with Aquamat ${ }^{\mathrm{TM}}$ than those without Aquamat ${ }^{\mathrm{TM}}$. This suggested that the Aquamat ${ }^{\mathrm{TM}}$ cannot remove all the dissolved inorganic nitrogen from the culture system for water quality management in a fish hatchery system.

\section{Acknowledgement}

Special thanks to the Ministry of Higher Education and Ministry of Science, Technology and Innovation of Malaysia for providing financial support under research grants of Fundamental FRG0041-ST-001 and Escience, SCF05-01-10SF0053, respectively. We also would like to thank deeply the staffs of Borneo Marine Research Institute fish hatchery.

\section{References}

1. ANZECC (2000) Australian and New Zealand Guidelines for Fresh and Marine Water Quality Management Strategy. Canberra: Australian and New Zealand Environment and Conservation Council, Australia.

2. Piedrahita RH (2003) Reducing the Potential Environmental Impact of Tank Aquaculture Effluents through Intensification and Recirculation. Aquaculture 226: 35-44.

3. Boyd CE, Tucker CS (1998) Pond Aquaculture Water Quality Management London: Kluwer Academic Publishers.

4. Diab S, Cochaba M, Mires D, Avinimelech $Y$ (1992) Combined IntensiveExtensive (CIE) Pond System, A: Inorganic Nitrogen Transformations. Aquaculture 101: 33-39.

5. Kumlu M, Eroldogan OT, Saglamtimur B (2007) The Effects of Salinity and Added Substrates on Growth and Survival of Metapenaeus monoceros (Decapoda: Penaeidae) Post-Larvae. Aquaculture 196: 177-188.

6. Sharrer MJ, Rishel K, Summerfelt S (2009) Evaluation of Geotextile Filtration Applying Coagulant and Flocculant Amendments for Aquaculture Biosolids Dewatering and Phosphorus Removal. Aquacultural Engineering 40: 1-10.

7. UNDP/FAO (1989) Site Selection Criteria for Marine Finfish Netcage Culture in Asia. UNDP/FAO Regional Seafarming Development and Demonstration Project Network of Aquaculture Centres in Asia. National Inland Fisheries Institute Kasetsart University, Bangkok Thailand.

8. Zweig RD, Morton JD, Stewart MM (1999) Source Water Quality for Aquaculture. A Guide for Assessment. Environmentally and Socially Sustainable Development. The World Bank. Washington, USA. 62p.
9. AMWQC, ASEAN Marine Water Quality Criteria (1999) ASEAN-Canada CPMSII Cooperative Programme on Marine Science. Marine Environment Division Water Quality Management Bureau, Pollution Control Department, Thailand.

10. Estim A (1999) Study on Dissolved Nutrients and Their Effects to The Population of Harmful Algal Blooms (Pyrodinium bahamense var compressum) in the Marine Waters of Sabah. Master Science Thesis. Universiti Malaysia Sabah, Malaysia.

11. Estim A (2010) Management of Water Quality in a Fish Hatchery System Doctorate of Philosophy Thesis. Universiti Malaysia Sabah. Malaysia.

12. Ennis J, Bilawa K (2000) Golf Course Ponds are Complete Ecosystems. Golf Course Manages 61-64.

13. Bratvold D, Browdy CL (2001) Effects of Sand Sediment and Vertical Surfaces (Aquamat ${ }^{\mathrm{TM}}$ ) on Production, Water Quality and Microbial Ecology in an Intensive Litopenaeus vannamei Culture System. Aquaculture 195: 81-94.

14. Scott S, Mcneil R (2001) Aquamats: How to Provide Habitat, Feed and Biofiltration for Hatchery and Nursery Tanks. Hatchery Int. 2: 19-21.

15. Parsons TR, Maita Y, Lali CMD (1984) A Manual of Chemical and Biological Methods for Seawater Analysis. Pergumon Press. Great Britian.

16. Stewart NT, Boardman GD, Helfrich LA (2006) Treatment of Rainbow Trout (Oncorhynchus mykiss) Raceway Effluent Using Baffled Sedimentaion and Artificial Substrates. Aquaculture Engineering 36: 166-178.

17. Ballester ELC, Wasielesky W, Cavalli RO, Abreu PC (2007) Nursery of the Pink Shrimp Farfantepenaeus Paulensis in Cages with Artificial Substrates: Biofilm Composition and Shrimp Performance. Aquaculture 269: 355-362.

18. Bianchini A, Wasielesky W, Jr, Filho KCM (1996) Toxicity of Nitrogenous Compounds to Juveniles of Flatfish, Paralichthys orbignyanus. Bullettin Environmental Contamination Toxicology 56: 453-459.

19. Kailasam M, Thirunavukkarasu AR, Abraham M, Chandra PK, Subburaj R (2002) Influence of Size Variation and Feeding on Cannibalism of Asian Sea Bass Lates calcarifer (Bloch) During Hatchery Rearing. Indian J Fish 49: 107 113.

20. Moss KRK, Moss SM (2004) Effects of Artificial Substrate and Stocking Densities of the Nursery Production of Pacific White Shrimp Litopenaeus vannamei. Journal World Aquaculture Society 35: 537-542.

21. Stehr G, Bo"Ttcher B, Dittberner P, Rath G (1995) The Ammonia-Oxidizing Nitrifying Population of the River Elbe Estuary. FEMS Microbiol. Ecol 17: 177186

22. Hargreaves JA (2006) Photosynthetic Suspended-Growth Systems in Aquaculture. Aquacultural Engineering 34: 344-363.

23. Henze M, Harremoes P, Arvin E, Cour Jansen J (1996) Waste Water Treatment Springer Verlag, Berlin. IWMI, 2000

24. Schneider O, Sereti V, Eding EH, Verreth JAJ (2005) Analysis of Nutrient Flows in Integrated Intensive Aquaculture Systems. Aquacultural Engineering 32: $379-401$ 